\title{
Erratum to: Struggles against subjection. Implications of criminalization of migration for migrants' everyday lives in Europe
}

\author{
Agnieszka Kubal
}

Published online: 30 December 2014

(C) Springer Science+Business Media Dordrecht 2014

\section{Erratum to: Crime Law Soc Change (2014) DOI 10.1007/s10611-014-9527-5}

'The author would like to clarify that in the article 'Struggles against subjection. Implications of criminalization of migration for migrants' everyday lives in Europe' published with the journal Crime, Law and Social Change, on p. 97 the reference to Amy Allen's (2013) Power and the subject. In C. Falzon, T. O’Leary, \& J. Sawicki (Eds.), Blackwell companions to philosophy: Companion to Foucault (pp. 301-319, Somerset: Wiley), pp. 345-346, should be acknowledged also in the second half of the paragraph. Also, on p. 100 the reference to Alessandro Spena (2013) Iniuria Migrandi: criminalization of immigrants and the basic principles of the criminal law, Criminal Law and Philosophy (pp. 1-23) pp. 4-5, should be acknowledged.'

These two articles are already included in the reference list under:

[4] Amy Allen's (2013) Power and the subject. In C. Falzon, T. O'Leary, \& J. Sawicki (Eds.), Blackwell companions to philosophy: Companion to Foucault (pp. 301-319, Somerset: Wiley

[69] Alessandro Spena (2013) Iniuria Migrandi: criminalization of immigrants and the basic principles of the criminal law, Criminal Law and Philosophy (pp. 1-23)

This brief Corrigendum is only to mark the reference to these articles more explicitly.

The online version of the original article can be found at http://dx.doi.org/10.1007/s10611-014-9527-5.

A. Kubal $(\triangle)$

British Academy Post-Doctoral Fellow, Centre for Socio-Legal Studies, University of Oxford, Manor Road Building, Oxford OX1 3UQ, UK

e-mail: agnieszka.kubal@csls.ox.ac.uk 